\title{
Interpretation of environmental gradients which influence sagebrush community distribution in northeastern Nevada
}

\author{
MARK E. JENSEN
}

\section{Abstract}

Sagebrush stands on the Humboldt National Forest, northeastern Nevada, were classified by two-way indicator species analysis (TWINSPAN) into 15 community types. Detrended correspondence analysis (DECORANA) was used to ordinate samples and plant species and characterize environmental gradients regulating community structure. Regression of soil attributes with sample ordination scores suggested that the plant communities respond to a complex gradient involving soil depth, water holding capacity, mollic epipedon thickness, clay content, and effective rooting depth. Soil chemical properties which displayed significant correlations with sample ordinations included $\mathrm{pH}$, base saturation, calcium, total nitrogen, organic matter, and phosphorus. These soil properties are considered to either directly influence or indirectly reflect the available soil moisture of a site. The transition from black sagebrush (Artemisia nova Nels.) to low sagebrush ( $A$. arbuscula Nutt.), basin big sagebrush (A. tridentata Nutt. ssp. tridentata) and mountain big sagebrush ( $A$. tridentata Nutt. ssp. vaseyana) stands along DECORANA Axis 1 appeared to represent a gradient of increasing available soil moisture. Elevation and aspect were not correlated with sample ordination scores. This lack of coorespondence is presumably due to various soil properties (e.g., depth, rock content, texture) which modify the direct effects of elevation and aspect on available soil moisture.

Key Words: habitat types, soil-rangeland relationships

Vegetation classifications have been developed for a variety of sagebrush-dominated rangelands of the western United States (Hironaka et al. 1983, Mueggler and Stewart 1980, Zamora and Tueller 1973). The various species and subspecies of the sagebrush genus Artemisia are commonly used in such work to differentiate between classification groups. This reliance on Artemisia is partly because of the indicator significance these species have in describing environmental conditions present at a site (Winward 1983).

Numerous authors suggest that sagebrush species respond primarily to moisture and temperature gradients in the landscape (Beetle 1979, Hironaka 1979, Hironaka et al. 1983, West et al. 1978). Direct measurements of either soil moisture or temperature are seldom made, however, with differences in elevation, aspect, or latitude typically used to infer climatic variation over a study area. To date, little quantitative information exists concerning the structure of sagebrush communities along environmental gradients in the Great Basin.

This paper summarizes the distribution of northern Nevada sagebrush community types and selected plant species along complex environmental gradients. A variety of measured soil properties are used to infer the primary gradients which influence plant species distribution. The synecological relationships suggested by the ordination analysis provide an understanding of how sagebrush community distribution is affected by changes in soil properties. Since community type classifications are commonly used to infer potential of the landscape for management activities, this

\footnotetext{
Author is regional soil scientist for the U.S. Forest Service, Regional Office, Missoula, Mont. 59807.

Manuscript accepted 15 June 1989.
}

understanding is critical to the improved management of western rangelands.

\section{Methods}

Vegetation and soil data were collected on 372 relatively undisturbed sagebrush-dominated rangeland sites of the Humboldt National Forest, northeastern Nevada (Fig. 1). Criteria for site

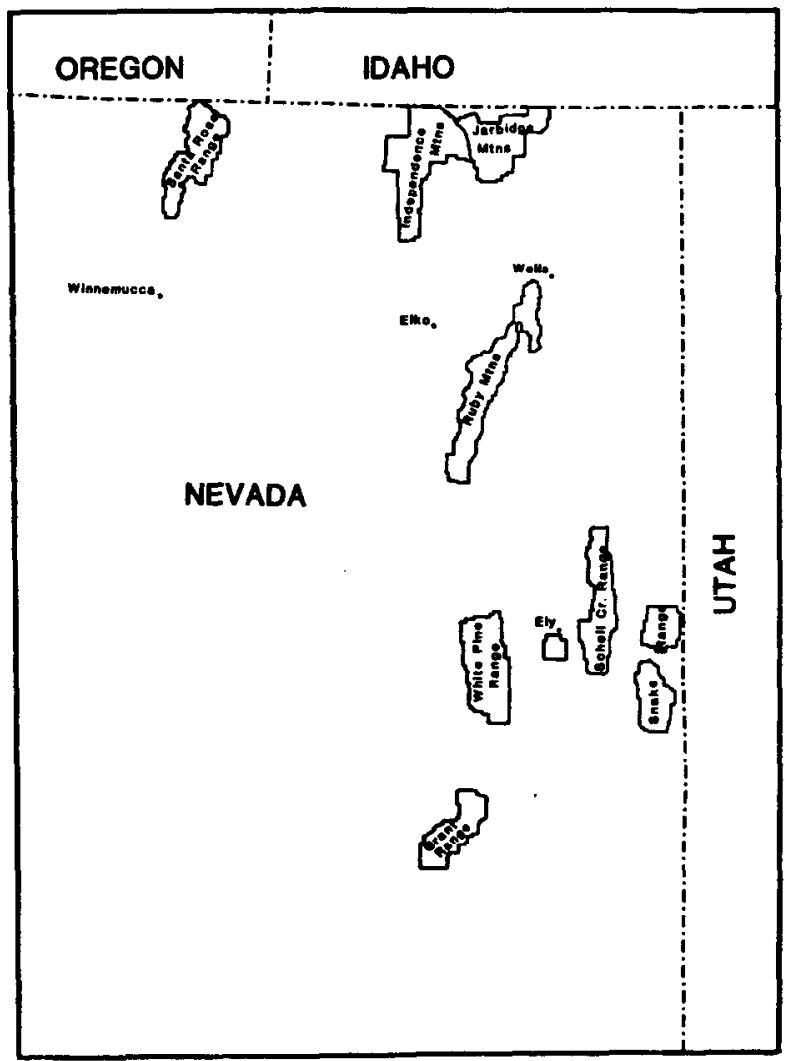

Fig. 1. The Humboldt National Forest of northeastern Nevada. The number of stands sampled per mountain range are: Grant $=19$, Independence $=127$, Jarbridge $=53$, Ruby $=17$, Schell $=52$, Snake $=66$, Santa Rosa $=15$, White Pine $=23$.

selection and the vegetation sampling methods employed have been described previously (Jensen et al. 1988). Sampling was conducted within a $323-\mathrm{m}^{2}$ macroplot located to represent the best available expression of the potential natural community of an ecological site (RISC 1983). Annual peak biomass production was determined by plant species in $10,2.93-\mathrm{m}^{2}$ circular microplots located randomly in the macroplot. A weight estimate method was used to determine plant species production with 2 microplots clipped at each site and cover estimates of production taken in the remaining microplots (Pechanec and Pickford 1937). Green weight production estimates were converted to dry weight values through use of conversion factors routinely used by Intermountain Region, U.S. Forest Service range personnel (USDA 1969). 
The majority of plants were identified to the species level during the period of field sampling. Specimens of unknown plant species were collected for taxonomic verification at the Univ. of NevadaReno Herbarium. Sagebrush species and subspecies were identified using morphological characteristics (Winward 1980) and verified using a simple chromatographic test based upon fluorescence in alcohol (Stevens and McArthur 1974). A subset of 50 sagebrush samples, which included samples of all sagebrush subspecies encountered on each mountain range, was taxonomically verified by high performance liquid chromatography (Rama et al. 1985) at the Dept. of Biochemistry, Univ. of Nevada-Reno. In all cases, field assessments of sagebrush species and subspecies corresponded with liquid chromatography results. Taxonomic nomenclature follows Cronquist et al. (1984).

Complete soil descriptions were made at each site to a depth of $1.5 \mathrm{~m}$ or to a shallower restrictive layer if present (e.g., lithic contact). Soils were classified to the family level of Soil Taxonomy (USDA 1975). Composite samples were collected for chemical and physical analysis at each pedon at 0-15 and 40-60 cm depths.

Soil analysis procedures follow Page et al. (1982). Analyses performed on surface $(0-15 \mathrm{~cm})$ and subsoil $(40-60 \mathrm{~cm})$ samples included: $\mathrm{pH}$ (1:2 soil to water ratio), extractable phosphorus (sodium bicarbonate method), extractable bases (ammonium acetate method), organic matter (Walkley-Black method), total soluble salts (electrical conductivity method), cation exchange capacity (ammonium acetate method), total nitrogen (micro-Kjeldahl method), extractable zinc and iron (DTPA method), calcium carbonate equivalent (gravimetric method), and particle size distribution (hydrometer method).

Soil morphology and site properties were described following procedures routinely used in U.S. Forest Service Land Systems Inventory (USDA 1980). Soil morphology properties recorded in the field for the A1, A2, and A, B, C master horizons were: water holding capacity (determined by a nomograph which included soil depth, texture, and rock fragment content); root abundance; texture; $\%$ clay content; $\%$ gravel cobble-stone and boulder content (by volume); \% total rocks; and horizon thickness. Site assessments of slope, aspect, elevation, rock type, infiltration, permeability, drainage, depth to restrictive layer, effective rooting depth (i.e., depth to where $80 \%$ of the roots terminate), total water holding capacity, erosion hazard, compaction, diagnostic horizons, and mollic epipedon thickness were also recorded for analysis. Various statistical analyses were performed utilizing programs contained in the Statistical Package for the Social Sciences (Norusis 1985) and the Cornell Ecology Series (Hill 1979).

A total of 15 sagebrush community types (Table 1) were identified through two-way indicator species analysis (TWINSPAN) of plant species production data considered over all sites (Jensen et al. 1988). The 372 samples by 219 species data matrix used in that analysis was ordinated with detrended correspondence analysis (DECORANA) (Hill 1979, Gauch 1982) to facilitate determination of environmental gradients which influence the distribution of sagebrush stands. The DECORANA algorithm simultaneously ordinates samples and plant species so that similar entities are located in close proximity while dissimilar entities are placed far apart. Since only community data are analyzed in DECORANA, environmental interpretation of ordination axes is a subsequent task for the user (Gauch 1982). The relative importance of environmental factors in determining community patterns was determined by regression of sample ordination scores with soil and site variables.

The units of ordination length developed in DECORANA indicate average standard deviations of species turnover (SD) and are identical to the $z$ value discussed by Gauch and Whittaker (1972). A species appears, rises to its mode, and disappears over a span of
Table 1. List of sagebrush community types and abbreviated codes referred to in the text.

\begin{tabular}{|c|c|}
\hline Abbreviate & Community Type \\
\hline RNO/AT & $\begin{array}{l}\text { Artemisia nova/Atriplex confertifolia/Sitanion } \\
\text { hystrix }\end{array}$ \\
\hline ARNO/ORHY & A. nova/Oryzopsis hymenoides \\
\hline SSP & A. nova/Agro \\
\hline SSP & A. arbuscula/Agrc \\
\hline ID $/$ & A. arbuscula/ Festuca idahoensis / Po \\
\hline תו' & A. arbuscula/Festu \\
\hline & A. longiloba/Fes \\
\hline A & $\begin{array}{l}\text { ntata ssp. wyomingensis/ Sitanion } \\
\text { ix }\end{array}$ \\
\hline ARTR/AGSP & $\begin{array}{l}\text { A. tridentata ssp. tridentata/Agropyron } \\
\text { spicatum }\end{array}$ \\
\hline AR & A. tridentata ssp. \\
\hline SP & A. $t$ \\
\hline ARVA/FEID & yana/Festuca idahoensis \\
\hline & A. tridentata ssp. vaseyana / Elymus cinereus \\
\hline ARV & $\begin{array}{l}\text { A. t. ssp. vaseyana/Symphoricarpos oreophilus/ } \\
\text { Agropyron spicatum }\end{array}$ \\
\hline CA & $\begin{array}{l}\text { A. } t \text {. ssp. vaseyana/Symphoricarpos oreophilus/ } \\
\text { Bromus carinatus }\end{array}$ \\
\hline
\end{tabular}

about $4 \mathrm{SD}$, while a $50 \%$ change in species distribution occurs in about 1 to $1.4 \mathrm{SD}$ units (Gauch 1982). In a similar manner, a full turnover in the species composition of a sample set (community type) occurs in about $4 \mathrm{SD}$, and a $50 \%$ change in species composition occurs between 1 and $1.4 \mathrm{SD}$ units. The absolute length of an ordination axis indicates the range of community gradient present and is useful in comparing various ordination axes developed within a particular study or ordination results from different data sets (Gauch 1982).

\section{Results and Discussion}

The first 2 axes of the DECORANA ordination provide information useful for interpreting the environmental gradients that

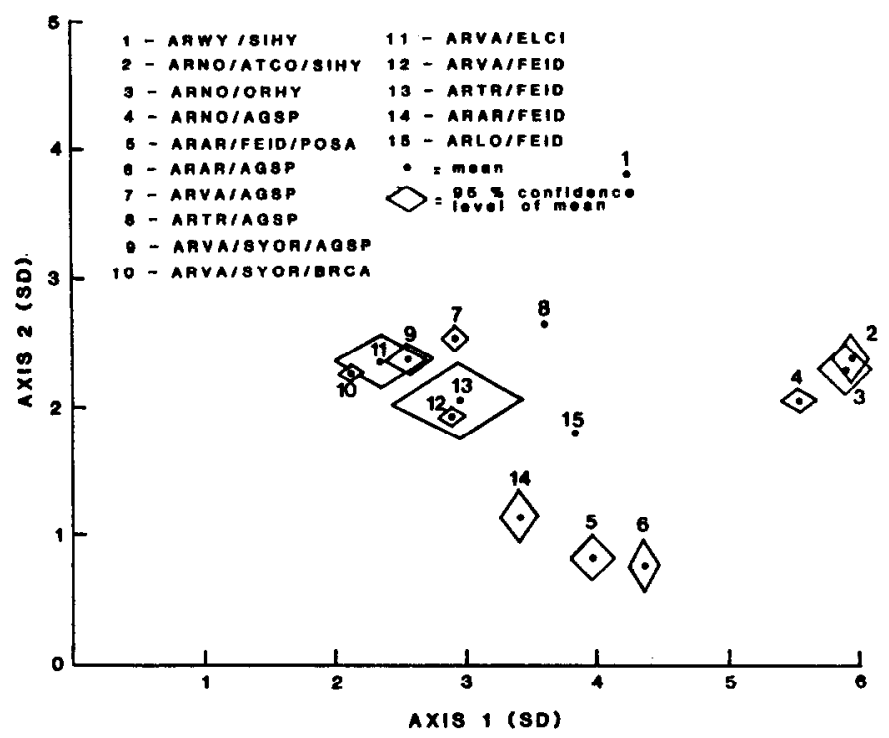

Fig. 2. Average DECORANA ordination scores by sagebrush community type. $\mathrm{SD}=$ standard deviation of species turnover. The rectangles provided represent $95 \%$ confidence levels associated with community type mean ordination scores along axes 1 and 2. Confidence levels are not provided for the ARWY/SIHY, ARTR/AGSP, and ARLO/FEID community types due to high variances and limited sampling in those types. 
Table 2. Listing of the major sagebrush community types of the Humboldt National Forest with general site characterizations provided.

\begin{tabular}{|c|c|c|c|c|c|c|c|}
\hline \multirow{2}{*}{$\frac{\text { Community type }}{\text { ARNO/ATCO/SIHY }}$} & \multirow{2}{*}{$\frac{\text { Sample size }}{12}$} & \multirow{2}{*}{$\begin{array}{l}\text { Principal soil } \\
\text { great group }\end{array}$} & \multirow{3}{*}{$\begin{array}{l}\begin{array}{l}\text { Elevation } \\
\text { range }(\mathrm{m})\end{array} \\
1829-2225 \\
1859-3048\end{array}$} & \multirow{2}{*}{$\begin{array}{c}\begin{array}{c}\text { Average } \\
\text { slope (\%) }\end{array} \\
23\end{array}$} & \multirow{3}{*}{$\begin{array}{c}\begin{array}{c}\text { Total number of } \\
\text { plant species ob- } \\
\text { served within type }\end{array} \\
50 \\
46\end{array}$} & \multicolumn{2}{|c|}{$\begin{array}{c}\text { Average annual dry } \\
\text { wt. prod. } \\
\text { (kg/ha) } \pm(\mathrm{SE})\end{array}$} \\
\hline & & & & & & 421 & (45) \\
\hline ARNO/ORHY & 16 & Paleorthids & & 15 & & 438 & (51) \\
\hline ARNO/AGSP & 44 & Calciorthids & $1829-3048$ & 20 & 58 & 482 & (25) \\
\hline ARAR/AGSP & 27 & Argixerolls & $1981-2926$ & 24 & 74 & 521 & (39) \\
\hline ARLO/FEID/POSA & 19 & Argixerolls & $1524-3109$ & 13 & 67 & 507 & (45) \\
\hline ARAR/FEID & 19 & Cryoborolls & $1768-2438$ & 13 & 56 & 627 & (50) \\
\hline ARLO/FEID & 4 & Argixerolls & $1829-1981$ & 6 & 27 & 484 & (66) \\
\hline ARWY/SIHY & 4 & Haploxerolls & $1829-2134$ & 4 & 45 & 595 & (18) \\
\hline ARTR/AGSP & 6 & Haploxerolls & $1707-1920$ & 20 & 25 & 726 & (187) \\
\hline ARTR/FEID & 8 & Haploxerolls & $1615-2103$ & 16 & 45 & 945 & (112) \\
\hline ARVA/AGSP & 63 & Cryoborolls & $1829-3048$ & 24 & 124 & 738 & (42) \\
\hline ARVA/FEID & 66 & Cryoborolls & $1707-2743$ & 17 & 93 & 786 & (44) \\
\hline ARVA/ELCI & 9 & Cryoborolls & $1859-2316$ & 33 & 49 & 1228 & (207) \\
\hline ARVA/SYOR/AGSP & 23 & Cryoborolls & $2012-2743$ & 26 & 88 & 938 & (90) \\
\hline ARVA/SYOR/BRCA & 46 & Cryoborolls & $1768-2499$ & 28 & 95 & 1188 & (99) \\
\hline
\end{tabular}

influence sagebrush community distribution (Fig. 2). Eigenvalues associated with ordination axes 1 and 2 were 0.75 and 0.46 , respectively. Confidence intervals of mean ordination score estimates are not provided for the ARWY/SIHY, ARTR/AGSP, and ARLO/ FEID community types because of high variances and limited sampling in those types. The sample size and general environmental features associated with each community type are summarized in Table 2.

The transition from mountain sagebrush ( $A$. tridentata Nutt. ssp. vaseyana) to basin big sagebrush ( $A$. tridentata Nutt. ssp. tridentata), low sagebrush ( $A$. arbuscula Nutt.), and black sagebrush ( $A$. nova Nels.) community types along axis 1 (Fig. 2) has been suggested to represent a gradient of decreasing soil moisture in other research (Hironaka et al. 1983, West et al. 1978, Miles and Leonard 1984). This assumption was tested by regressing soil and site variables with DECORANA sample scores (Table 3). Ten of

Table 3. Pearson correlation coefficients between sample DECORANA ordination scores and soil morphological-site variables.

\begin{tabular}{lcc}
\hline & \multicolumn{2}{c}{ DECORANA } \\
\hline & 1 & 2 \\
Parameter & -0.44 & 0.35 \\
Soil depth & -0.40 & 0.18 \\
Total water holding capacity & -0.40 & 0.16 \\
Effective rooting depth & -0.38 & 0.31 \\
Mollic epipedon depth & 0.34 & 0.29 \\
C horizon thickness & -0.31 & 0.17 \\
A horizon depth & NS & -0.29 \\
A horizon clay content & NS & -0.29 \\
B horizon clay content & -0.27 & NS \\
A horizon water holding capacity & -0.16 & 0.13 \\
Slope &
\end{tabular}

Note: Only high significant $(P<0.01)$ variables are presented. NS = not significant.

the soil and site variables examined displayed significant $(P<0.01)$ negative correlations with sample ordination scores. These variables indicate that DECORANA axis 1 represents a gradient of decreasing soil depth, water holding capacity, effective rooting depth, and mollic epipedon thickness (Table 3). These factors, in turn, directly influence the amount of water a plant can effectively utilize, which suggests that axis 1 indicates an available soil moisture gradient. Axis 2 provides less information than axis 1; however, it appears that a gradient of decreasing clay content and increasing soil depth is present along this axis.

Seasonal amounts of available soil moisture at a site are usually inferred from elevation and aspect (West et al. 1978). Elevation and aspect were not significantly correlated with sample ordination scores in this study. This lack of correspondence is presumably due to other soil properties (e.g., depth, rock content, texture) which modify the direct effects elevation and aspect have on available soil mositure.

Correlation between soil chemical variables and sample ordination scores also suggest axis 1 represents a gradient of decreasing soil moisture (Table 4). Soil variables such as $\mathrm{pH}$, base saturation,

Table 4. Pearson correlation coefficients between sample DECORANA ordination scores and soil chemical variables.

\begin{tabular}{lcc}
\hline \hline & \multicolumn{2}{c}{ DECORANA Axis } \\
Parameter & 1 & 2 \\
\hline Surface pH & 0.57 & NS \\
Subsoil pH & 0.61 & NS \\
Surface base saturation & 0.49 & NS \\
Subsoil base saturation & 0.39 & NS \\
Surface sodium content & 0.27 & NS \\
Subsoil sodium content & 0.38 & NS \\
Surface calcium content & 0.34 & NS \\
Subsoil calcium content & 0.21 & NS \\
Surface calcium carbonate equivalent & 0.32 & NS \\
Subsoil calcium carbonate equivalent & 0.36 & NS \\
Surface carbon-nitrogen ratio & 0.23 & NS \\
Surface total nitrogen content & -0.53 & NS \\
Surface zinc content & -0.47 & 0.31 \\
Subsoil zinc content & -0.29 & 0.27 \\
Surface organic matter content & -0.32 & NS \\
Subsoil organic matter content & -0.26 & NS \\
Surface phosphorus content & -0.37 & 0.21 \\
Subsoil phosphorus content & -0.24 & NS \\
Subsoil magnesium-potassium ratio & NS & -0.33 \\
\hline
\end{tabular}

Note: Only highly significant $(P<0.01)$ variables are presented. NS = not significant. Surface and subsoil refer to $0-15$ and $40-60 \mathrm{~cm}$ depths, respectively.

sodium and calcium content, which tend to reach maximum levels under conditions of minimal leaching (Birkeland 1984), display significant positive correlations with axis 1 ordination scores. Conversely, soil variables which attain maximum levels under higher available soil moisture levels (i.e., total nitrogen, organic matter, zinc, and phosphorus content [Jenny 1980]) display significant negative correlations.

The transition in community types along DECORANA axis 1 (Fig. 2) is in response to lower available soil moisture as inferred by soil morphology and chemistry data. Multiple range tests of average tendencies in soil morphological variables (Table 5) and soil 
Table 5. Comparison of average soil morphological property values by plant community type.



*Means underlined by the same line are not significantly different $(P<0.05)$ as determined by Duncan's Multiple Range Test.

chemical variables (Table 6 ) across the community types further illustrate this point.

Community types with black sagebrush as the dominant shrub species tend to have the lowest water holding capacities, mollic epipedon thickness, organic matter, and nitrogen contents (Tables 5 and 6 ), which suggests that they occupy the most xeric end of the community gradient described. The mixed mountainbrush (ARVA/SYOR/BRCA and ARVA/SYOR/AGSP), and ARVA/ FEID community types tend to display highest average values for

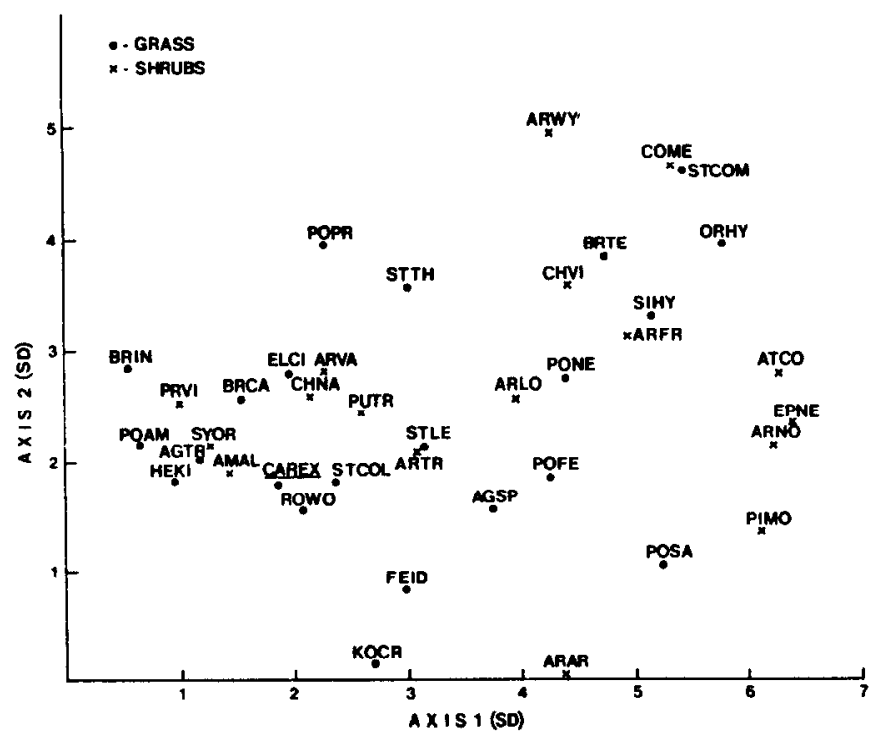

Fig.3. DECORANA ordination of the dominant and indicator shrub and grass species comprising the sagebrush community types. $\mathrm{SD}=$ standard deviation of species tumover. these soil variables, indicating that they represent the more mesic end of the gradient. Community types which ordinate between these extremes (e.g., ARAR/AGSP, ARVA/AGSP) display intermediate values for these soil variables.

Ordination of plant species by DECORANA facilitates the inspection of autecological trends in plant distribution (Figs. 3 and 4). Since the DECORANA algorithm simultaneously ordinates both samples and species (Hill 1979), the correlations developed between soil parameters and sample ordination scores (Tables 3 and 4) may be used to infer plant species response.

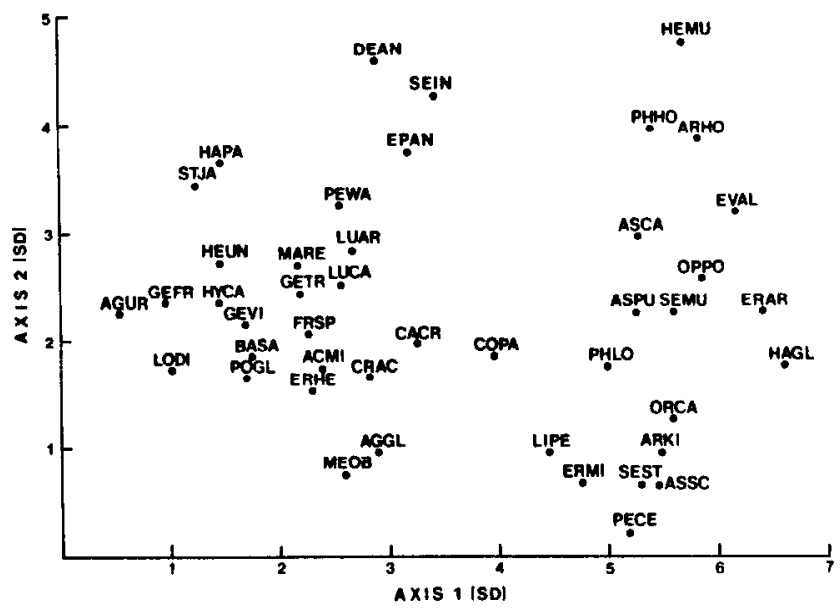

Fig. 4. DECORANA ordination of the dominant and indicator forb species comprising the sagebrush community types. SD = standard deviation of species turnover. 
Table 6. Comparison of average soil surface $(0-15 \mathrm{~cm})$ chemical property values by plant community type.

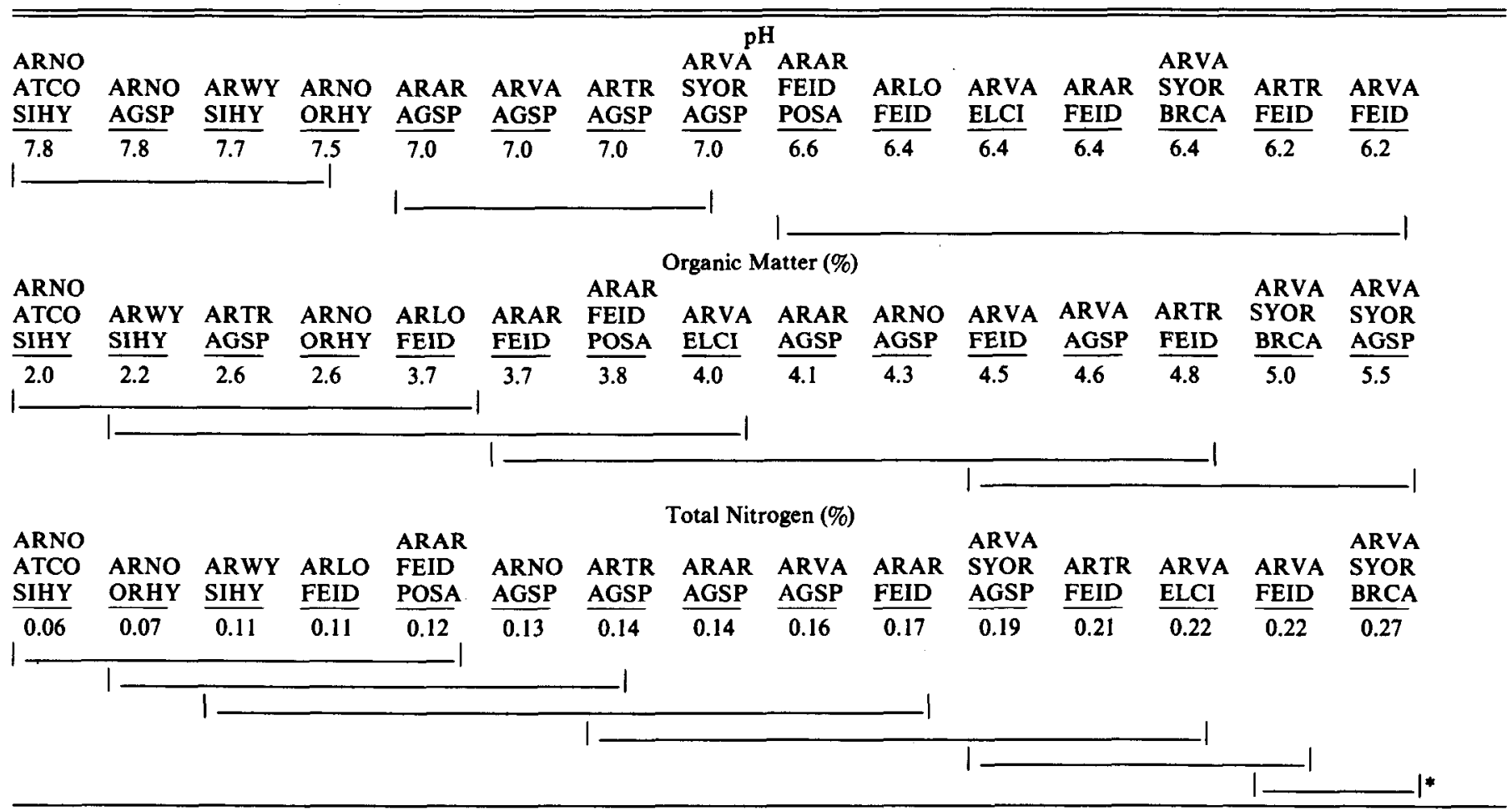

* Means underlined by the same line are not significantly different $(P<0.05)$ as determined by Duncan's Multiple Range Test.

Table 7. Listing of abbreviations and corresponding scientific names for dominant and indicator grass and shrub species referred to in the text.

\begin{tabular}{|c|c|c|c|}
\hline \multicolumn{2}{|r|}{ Grasses } & \multicolumn{2}{|r|}{ Shrubs } \\
\hline Abbreviation & Scientific Name & Abbreviation & Scientific Name \\
\hline $\begin{array}{l}\text { AGSP } \\
\text { AGTR } \\
\text { BRCA } \\
\text { BRIN } \\
\text { BRTE } \\
\text { CAREX } \\
\text { ELCI } \\
\text { FEID } \\
\text { KOCR } \\
\text { ORHY } \\
\text { POAM } \\
\text { POFE } \\
\text { PONE } \\
\text { POPR } \\
\text { POSA } \\
\text { SIHY } \\
\text { STCOL } \\
\text { STCOM } \\
\text { STLE } \\
\text { STTII }\end{array}$ & $\begin{array}{l}\text { Agropyron spicatum } \\
\text { Agropyron trachycaulum } \\
\text { Bromus carinatus } \\
\text { Bromus inermis } \\
\text { Bromus tectorum } \\
\text { Carex spp. } \\
\text { Elymus cinereus } \\
\text { Festuca idahoensis } \\
\text { Koelaria cristata } \\
\text { Oryzopsis hymenoides } \\
\text { Poa ampla } \\
\text { Poa fendleriana } \\
\text { Poa nevadensis } \\
\text { Poa pratensis } \\
\text { Poa sandbergii } \\
\text { Sitanion hystrix } \\
\text { Stipa columbiana } \\
\text { Stipa comata } \\
\text { Stipa lettermanii } \\
\text { Stipa thruberiana }\end{array}$ & $\begin{array}{l}\text { AMAL } \\
\text { ARAR } \\
\text { ARFR } \\
\text { ARLO } \\
\text { ARNO } \\
\text { ARTR } \\
\text { ARVA } \\
\text { ARWY } \\
\text { ATCO } \\
\text { CHNA } \\
\text { CHVI } \\
\text { COME } \\
\text { EPNE } \\
\text { PRVI } \\
\text { PUTR } \\
\text { SYOR }\end{array}$ & $\begin{array}{l}\text { Amelanchier alnifolia } \\
\text { Artemisia arbuscula } \\
\text { Artemisia frigida } \\
\text { Artemisia longiloba } \\
\text { Artemisia nova } \\
\text { Artemisia tridentata ssp. tridentata } \\
\text { Artemisia tridentata ssp. vaseyana } \\
\text { Artemisia tridentata ssp. wyomingensis } \\
\text { Atriplex confertifolia } \\
\text { Chrysothamnus nauseosus } \\
\text { Chrysothamnus viscidiflorus } \\
\text { Cowania mexicana } \\
\text { Ephedra nevadensis } \\
\text { Prunus virginiana var. melanocarpa } \\
\text { Purshia tridentata } \\
\text { Symphoricarpos oreophilus }\end{array}$ \\
\hline
\end{tabular}

Species which occupy extreme positions along ordination axes are more restricted in their distribution across the community gradient sampled, while those in the center tend to be more ubiquitous. Grass species such as basin wild rye (Elymus cinereus Scribn.), mountain brome (Bromus carinatus H.), and slender wheatgrass (Agropyron trachycaulum Scribn.) on the left side of ordination axis 1 (Fig. 3) are restricted to relatively mesic sites. Snowberry (Symphoricarpos oreophilus L.) and serviceberry (Amelanchier alnifolia Nutt.) are shrubs commonly found growing with these grasses. Plants such as black sagebrush and Indian ricegrass (Oryzopsis hymenoides $\mathbf{R}$. ts.), which occur on the right side of ordination axis 1 (Fig. 3), are indicative of relatively xeric environments. Those species located near the middle of axis 1 [e.g., bluebunch wheatgrass (Agropyron spicatum Pursh.), bluegrass (Poa fendleriana Steud.), and green rabbit-brush (Chrysothamnus viscidiflorus Nutt.)] occupy a wide range of environment but are most abundant on sites with soil properties intermediate between these extremes. The trend in plant species distribution suggested by ordination axis 2 (Fig. 3) is from species adapted to shallower heavy clay soils (i.e., low sagebrush) to those which occur on 
Table 8. Listing of abbreviations and corresponding scientific names for dominant and indicator forb species referred to in the text.

\begin{tabular}{|c|c|c|c|}
\hline Abbreviation & Scientific Name & Abbreviation & Scientific Name \\
\hline $\begin{array}{l}\text { ACMI } \\
\text { AGGL } \\
\text { AGUR } \\
\text { ARHO } \\
\text { ARKI } \\
\text { ASCA } \\
\text { ASPU } \\
\text { ASSC } \\
\text { BASA } \\
\text { CACR } \\
\text { COPA } \\
\text { CRAC } \\
\text { DEAN } \\
\text { EPAN } \\
\text { ERAR } \\
\text { ERHE } \\
\text { ERMI } \\
\text { EUAL } \\
\text { FRSP } \\
\text { GEFR } \\
\text { GETR } \\
\text { GEVI }\end{array}$ & $\begin{array}{l}\text { Achillea millefolium } \\
\text { Agoseris glauca } \\
\text { Agastache urticifolia } \\
\text { Arabis holboellii } \\
\text { Arenaira Kingii } \\
\text { Asatragalus calycosus } \\
\text { Astragalus purshii } \\
\text { Aster scopulourm } \\
\text { Balsamorhiza sagittata } \\
\text { Castilleja chromosa } \\
\text { Commandra pallida } \\
\text { Crepis acuminata } \\
\text { Delphinium andersonii } \\
\text { Epilobium angustifolium } \\
\text { Erigeron argenteus } \\
\text { Eriogonum heracleoides } \\
\text { Eriogonum microthecum } \\
\text { Euphorbia albomorginata } \\
\text { Frasera speciosa } \\
\text { Geranium fremontii } \\
\text { Geum triflorum } \\
\text { Geranium viscosissimum }\end{array}$ & $\begin{array}{l}\text { HAGL } \\
\text { HAPA } \\
\text { HEMU } \\
\text { HEUN } \\
\text { HYCA } \\
\text { LIPE } \\
\text { LODI } \\
\text { LUAR } \\
\text { LUCA } \\
\text { MARE } \\
\text { MEOB } \\
\text { OPPO } \\
\text { ORCA } \\
\text { PECE } \\
\text { PEWA } \\
\text { PHHO } \\
\text { PHLO } \\
\text { SEIN } \\
\text { SEMU } \\
\text { SEST } \\
\text { STJA } \\
\text { WYAM }\end{array}$ & $\begin{array}{l}\text { Halogeton glomeratus } \\
\text { Hackelia patens } \\
\text { Heliomeris multiflora } \\
\text { Helianthella uniflora } \\
\text { Hydrophyllum capitatum } \\
\text { Linum perenne } \\
\text { Lomatium dissectum } \\
\text { Lupinus argenteus } \\
\text { Lupinus caudatus } \\
\text { Mahonia repens } \\
\text { Mertensia obliogifolia } \\
\text { Opuntia polyacantha } \\
\text { Orobanche californica } \\
\text { Pediculuaris centranthera } \\
\text { Penstomen watsonii } \\
\text { Phlox hoodii } \\
\text { Phlox longifolia } \\
\text { Senecio integerrimus } \\
\text { Senecio multilobatus } \\
\text { Sedum stenopetalum } \\
\text { Stellaria jamesiana } \\
\text { Wyethia amplexicaulis }\end{array}$ \\
\hline
\end{tabular}

deeper, lighter textured soils [i.e., Wyoming sagebrush (A. tridentata Nutt. ssp. wyomingensis)]. Forb species (Fig. 4) respond to environmental gradients similar to those identified in the sample (Fig. 2) and grass plus shrub species (Fig. 3) ordinations.

Plant species separated by more than 4 SD units along axis 1 are rarely found growing together in the study area. The ordination of grass plus shrub species (Fig. 3) suggests that black sagebrush, spiny saltbush (Atriplex confertifolia Torr. + Frem), and Indian ricegrass seldom occur on sites which support snowberry, mountain brome, or slender wheatgrass. The position of cheatgrass (Bromus tectorum L.) and green rabbit-brush in this ordination indicates that they are likely to show maximum expression upon disturbance of community types whose dominant grass species are bluebunch wheatgrass, squirreltail (Sitanion hystrix Nutt.), Nevada bluegrass (Poa nevadensis Vasey), Indian ricegrass, muttongrass (Poa fendleriana Steud.), or Sandberg's bluegrass (Poa sandbergii Vasey), such as the ARWY/SIHY, ARNO/AGSP, and ARVA/AGSP community types.

\section{Conclusions}

Sagebrush community types in the study area follow an apparent gradient of available soil moisture as inferred from regression of sample DECORANA ordination scores with soil variables which either directly influence the soil's ability to hold water (e.g., depth, clay content) or reflect its long-term moisture status (e.g., $\mathrm{pH}$, base saturation). In that the sagebrush communities studied follow predictable changes in important soil properties, they may be used in a general manner to infer site potentials for management. There is, however, considerable variation in the range of environments occupied by certain community types (e.g., ARVA/ AGSP). This suggests caution be employed when inferring management potentials of the landscape solely from plant community presence.

\section{Literature Cited}

\section{References}

Beetle, A.A. 1979. Autecology of selected woody sagebrush species. In: The Sagebrush Ecosystem: A Symposium. April, 1978. Utah State Univ., Logan.

Birkeland, P.W. 1984. Soils and geomorphology. Oxford Univ. Press Inc., New York, NY.
Cronquist, A., H.H. Holmgran, N.H. Holmgran, J.L. Reveal, and P.K. Holmgren. 1984. Intermountain flora. Vol. 4. New York Botanical Garden, Bronx, NY.

Gauch, H.G. 1982. Multivariate analysis in community ecology. Cambridge Univ. Press. Cambridge, England.

Gauch, H.G., and R.H. Whittaker. 1972. Coenocline simulation. Ecology $53: 446-451$.

Hill, M.D. 1979. DECORANA-a FORTRAN program for detrended correspondence analysis and reciprocal averaging. Cornell Univ., Ithaca, NY.

Hironaka, M. 1979. Basic synecological relationships of the Columbia River sagebrush type. In: The Sagebrush Ecosystem: A Symposium. April 1978. Utah State Univ.

Hironaka, M., M.A. Fosberg, and A.H. Winward. 1983. Sagebrush-grass habitat types of southern Idaho. Bull. 35. Univ. Idaho Forest Wildl. and Range Exp. Sta., Moscow.

Jensen, M.E., L.S. Peck, and M.V. Wilson. 1988. A sagebrush community type classification for mountainous northeastern Nevada rangelands. Great Basin Natur. 48:422-433.

Jenny, H. 1980. The soil resource-origin and behavior. Springer-Verlag Pub., New York, NY.

Miles, R.L., and S.G. Leonard. 1984. Documenting soil-plant relationships of selected sagebrush species using the Soil Resource Information System. Soil Survey Horizons 25:22-26.

Mueggler, W.F., and W.L.Stewart. 1980. Grassland and shrubland habitat types of western Montana. USDA Forest Serv. Gen. Tech. Rep. INT-66, Intermt. Forest and Range Exp. Sta., Ogden, Utah.

Norusis, M.J. 1985. Statistical package for the social sciences. SPSS Inc., Chicago, Ill.

Page, A.L., R.H. Miller, and D.R. Keeney (eds.). 1982. Methods of soil analysis. Agron. Monog. 9, parts 1 and 2. Amer. Soc. Agron. Madison, Wisc.

Pechanec, J.F., and G.D. Pickford. 1937. A weight estimate method for determinations of range or pasture production. J. Amer. Soc. Agron. 29:894-904.

Rama, V.T., G.C. Miller, and R. Everett. 1985. High performance liquid chromatography analysis of coumarins and flavonoids from section Tridentatae of artemisia. J. Chromato. 322:236-239.

RISC. 1983. Guidelines and terminology for range inventories and monitoring. Rep. Range Inventory Standardization Committee. Soc. Range Manage., Denver, Colo.

Stevens, R., and E.D. McArthur. 1974. A simple field technique for identification of some sagebrush taxa. J. Range Manage. 27:325-326.

USDA. 1969. Range environmental analysis handbook. USDA Forest Service, Intermountain Region, Ogden, Utah.

USDA. 1975. Soil taxonomy. Soil Survey Staff, USDA Agr. Handb. 436, U.S. Gov. Printing Office, Washington, D.C. 
USDA. 1980. Procedural guide for land systems inventory. USDA Forest Serv., Intermount. Reg., Ogden, Utah.

West, N.E., R.J. Trusch, K.H. Rea, P.T. Tueller. 1978. Taxonomic determination, distribution, and ecological indicator values of sagebrush within the pinyon juniper woodlands of the Great Basin. J. Range Manage. 31:87-92.

Winward, A.H. 1980. Taxonomy and ecology of sagebrush in Oregon. Agr. Exp. Sta. Bull. 642, Oregon State Univ., Corvallis, Ore.
Winward, A.H. 1983. Using sagebrush ecology in wildland management. In: K.L. Johnson (ed.) First Utah shrub ecology workshop Proc. Utah State Univ., Logan.

Zamora, B., and P.T. Tueller. 1973. Artemisia arbuscula, A. longiloba, and $A$. nova habitat types in northern Nevada. Great Basin Natur. 33:225-242. 